\title{
Pengaruh gaya kepemimpinan demokratis, motivasi dan disiplin kerja terhadap kinerja pegawai pada kantor bapelkes provinsi kalimantan tengah
}

\author{
Rivan Ti Tomi ${ }^{1)}$, Jonfrid Siae ${ }^{2)}$,Olivia Winda Ony Panjaitan ${ }^{3)}$ \\ Fakultas Ekonomi dan Bisnis Universitas Palangka Raya, Indonesia
}

\begin{abstract}
Abstrak
Tujuan, - Penelitian ini ditujukan untuk mengetahui apakah gaya kepemimpinan demokratis, motivasi dan disiplin kerja berpengaruh terhadap kinerja pegawai pada Kantor BAPELKES Provinsi Kalimantan Tengah.

Desain/Methodologi/Pendekatan - Jenis penelitian eksplanatori dengan pendekatan kuantitatif. Data yang terkumpul dianalisis dengan menggunakan pendekatan Uji Statistik Deskriptif, Validitas, Reliabilitas, Asumsi klasik, Analisis Regresi Berganda, Uji t Uji F, dan Koefisien Determinasi, software yang digunakan adalah Statistical Package for the Social Sciences (SPSS) versi 22.0.

Temuan penelitian - Hasil penelitian menunjukkan bahwa : (1) gaya kepemimpinan demokratis berpengaruh positif dan signifikan terhadap kinerja pegawai, (2) motivasi berpengaruh positif dan signifikan terhadap kinerja pegawai, (3) disiplin kerja berpengaruh positif dan signifikan terhadap kinerja pegawai, dan (4) gaya kepemimpinan demokratis, motivasi dan disiplin kerja berpengaruh positif dan signifikan terhadap kinerja pegawai pada kantor BAPELKES Provinsi Kalimantan Tengah.
\end{abstract}

Kata kunci: Kepemimpinan Demokratis, Motivasi, Disiplin Kerja, Kinerja Pegawai Jenis artikel: Artikel penelitian

\section{The influence of democratic leadership style, motivation and work discipline on employee performance at bapelkes office of central kalimantan province}

\begin{abstract}
Purpose, - This study aims to determine whether democratic leadership style, motivation and work discipline affect employee performance at the BAPELKES Office of Central Kalimantan Province. Design/methodology/approach - The type of research is explanatory with a quantitative approach. The collected data were analyzed using the descriptive statistical test approach, validity, reliability, classical assumptions, multiple regression analysis, $t$-test $F$ test, and coefficient of determination, the software used was the Statistical Package for the Social Sciences (SPSS) version 22.0.

Findings - The results showed that: (1) democratic leadership style has a positive and significant effect on employee performance, (2) motivation has a positive and significant effect on employee performance, (3) work discipline has a positive and significant effect on employee performance, and (4) leadership style democracy, motivation and work discipline have a positive and significant effect on employee performance at the BAPELKES office of Central Kalimantan Province.
\end{abstract}




\section{Pendahuluan}

Era sekarang, setiap organisasi diharuskan melakukan suatu perubahan yang dinamis mengikuti apa yang dihadapkan di masa tersebut. Berdasarkan hasil observasi yang dilakukan pada bulan Maret 2020 diketahui bahwa menurunnya kinerja pegawai di kantor BAPELKES disebabkan oleh gaya kepemimpinan, kedisiplinan, dan motivasi kerja. Kedisiplinan kerja pegawai terlihat dari ketepatan waktu datang ke kantor, terutama ketika ada kegiatan pagi seperti upacara dan senam pagi, kemungkinan terjadinya keterlambatan setiap hari sekitar 34 orang pegawai. Hal ini juga berdasarkan hasil wawancara langsung dari beberapa pegawai BAPELKES. Selain dilihat dari keterlambatan dalam waktu datang ke kantor, menurunnya kedisiplinan pegawai juga dapat dilihat dari kehadiran atau absensi yang dilakukan pegawai. Selain itu, berdasarkan hasil data evaluasi kriteria penilaian pegawai tahun 2019 menunjukkan bahwa motivasi yang dimiliki pegawai BAPELKES yang dilihat dari hasil orientasi dan integritas pegawai masih didominasi kisaran cukup baik antara nilai skor 76-80

Hasil penelitian secara parsial dan simultan menunjukkan bahwa gaya kepemimpinan, motivasi dan disiplin kerja berpengaruh signifikan terhadap kinerja pegawa. Penelitian yang dilakukan oleh Susanto (2019) hasil penelitian menunjukan bahwa motivasi kerja memiliki pengaruh terhadap kinerja karyawan, kepuasan kerja memiliki pengaruh terhadap kinerja karyawan dan disiplin kerja memiliki pengaruh terhadap kinerja karyawan. Penelitian yang dilakukan Tri Susanti, dkk (2017), hasil penelitian menunjukkan bahwa gaya kepemimpinan demokratis berpengaruh positif terhadap kinerja karyawan. Penelitian yang dilakukan oleh Bryan Johannes (2014) hasil penelitian menunjukkan bahwa gaya kepemimpinan dan motivasi pengaruh positif dan signifikan terhadap kinerja karyawan.

Berdasarkan permasalahan tersebut maka dirumuskan suatu pertanyaan penelitian sebagai berikut: (1). Apakah gaya kepemimpinan demokratis berpengaruh terhadap kinerja pegawai pada Kantor BAPELKES Provinsi Kalimantan Tengah? (2). Apakah motivasi berpengaruh terhadap kinerja pegawai pada Kantor BAPELKES Provinsi Kalimantan Tengah? (3). Apakah disiplin kerja berpengaruh terhadap kinerja pegawai pada Kantor BAPELKES Provinsi Kalimantan Tengah? (4). Apakah gaya kepemimpinan demokratis, motivasi dan disiplin kerja berpengaruh terhadap kinerja pegawai pada Kantor BAPELKES Provinsi Kalimantan Tengah?

Tujuan penelitian ini adalah untuk mengetahui: (1). Untuk mengetahui apakah gaya kepemimpinan demokratis berpengaruh terhadap kinerja pegawai pada Kantor BAPELKES Provinsi Kalimantan Tengah. (2). Untuk mengetahui apakah motivasi berpengaruh terhadap kinerja pegawai pada Kantor BAPELKES Provinsi Kalimantan Tengah. (3). Untuk mengetahui apakah disiplin kerja berpengaruh terhadap kinerja pegawai pada Kantor BAPELKES Provinsi Kalimantan Tengah. (4). Untuk mengetahui apakah gaya kepemimpinan demokratis, motivasi dan disiplin kerja berpengaruh terhadap kinerja pegawai pada Kantor BAPELKES Provinsi Kalimantan Tengah

Manfaat-manfaat yang diharapkan dari penelitian ini adalah dapat menambah pengetahuan sebagai bekal dalam menerapkan ilmu yang telah diperoleh dibangku kuliah dalam dunia kerja yang sesungguhnya, diharapkan hasil penelitian ini dapat memberikan informasi yang berharga bagi BAPELKES dalam pengelolaan SDM beserta segala kebijakan yang berkaitan langsung dengan aspek-aspek SDM secara lebih baik, hasil dari penelitian ini diharapkan dapat menambah informasi dan referensi bacaan bagi semua pihak. 


\section{Kajian Pustaka}

\section{Kinerja}

Kinerja adalah suatu hasil kerja dan perilaku kerja yang telah dicapai dalam menyelesaikan tugas-tugas dan tanggung jawab yang diberikan dalam suatu periode tertentu dibandingkan dengan kemungkinan, misalnya standar, target atau sasaran kriteria yang telah ditentukan dan disepakati terlebih dahulu secara bersama-sama (Kasmir, 2016).

\section{Gaya Kepemimpinan Demokratis}

Gaya kepemimpinan demokratis menurut Thoha (2013), gaya ini dikaitkan dengan kekuatan personal dan keikutsertaan para pengikut dalam proses pemecahan masalah dan pengambilan keputusan.

\section{Motivasi}

Veithzal (2010) menyatakan bahwa motivasi adalah serangkaian sikap dan nilai-nilai yang mempengaruhi individu untuk mencapai hal yang spesifik sesuai dengan tujuan individu.

\section{Disiplin Kerja}

Disiplin kerja menurut Rivai (2012), disiplin kerja adalah suatu alat yang digunakan untuk berkomunikasi dengan karyawan agar mereka bersedia untuk mengubah suatu perilaku serta sebagai suatu upaya untuk meningkatkan kesadaran dan kesediaan seseorang menaati semua peraturan perusahaan dan norma-norma sosial yang berlaku.

Gambar 1. Kerangka Penelitian

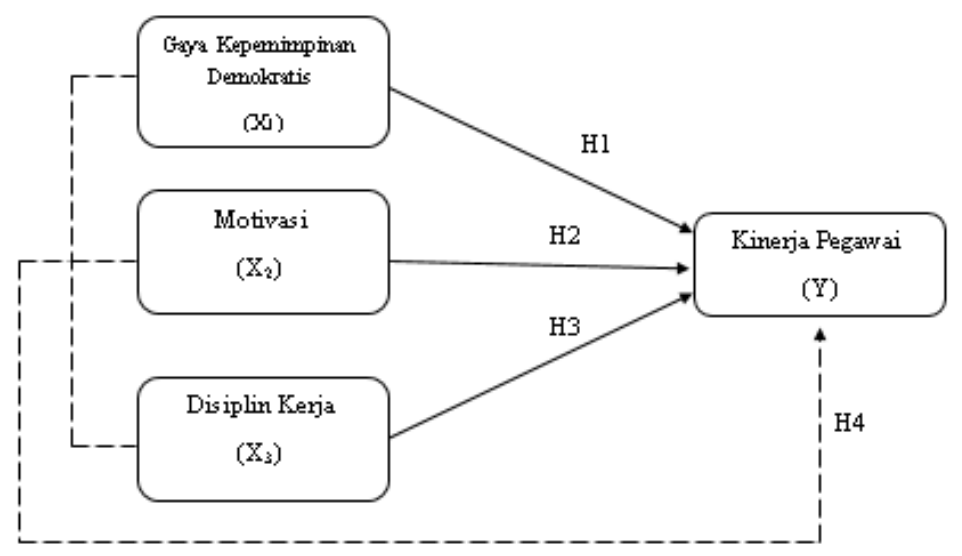

\section{Metode Penelitian}

Penelitian berlokasi di kantor Badan Pelatihan Kesehatan (BAPELKES) Provinsi Kalimantan Tengah, terletak di Jalan Yos Sudarso No. 14, Palangka Raya dengan luas bangunan adalah 3.778,4 $\mathrm{m} 2$. Dengan jumlah responden sebanyak 36 orang populasi dan sampel sebanyak 36 orang dengan menggunakan teknik sampling jenuh.

Ruang lingkup penelitian ini adalah penelitian eksplanatori dengan pendekatan kuantitatif. Metode penelitian yang digunakan dalam penelitian ini adalah pendekatan deskriptifkuantitatif bertujuan untuk mengetahui apakah terdapat Pengaruh Gaya Kepemimpinan Demokratis, Motivasi dan Disiplin Kerja terhadap Kinerja Pegawai pada Kantor BAPELKES Provinsi Kalimantan Tengah. Mengingat jumlah populasi hanya sebesar 36 pegawai, sehingga peneliti menggunakan teknik sampling jenuh. Menurut Sugiyono (2014) sampling jenuh adalah teknik penentuan sampel bila anggota populasi digunakan sebagai sampel. Hal ini 
sering dilakukan bila jumlah populasi relatif kecil, kurang dari 30 orang, atau penelitian yang ingin membuat generalisasi dengan kesalahan yang sangat kecil.

Kriteria penilaian ini digolongkan dalam empat tingkatan dengan penilaian, dari Jurnal Prinsip Penulisan Kuesioner Penelitian dari Isti Pujihastuti : 2010 mengungkapkan bahwa untuk penelitian di Indonesia disarankan menggunakan skala Likert genap misalnya dengan 4 tingkat (berarti skala genap) sebab terdapat kecenderungan bahwa individu di Indonesia cenderung bersikap netral, apabila demikian responden lebih mempunyai sikap kepada setuju atau tidak setuju.

a. Skor 4 diberikan untuk jawaban sangat setuju

b. Skor 3 diberikan untuk jawaban setuju

c. Skor 2 diberikan untuk jawaban tidak setuju

d. Skor 1 diberikan untuk jawaban sangat tidak setuju

Untuk menganalisis setiap pertanyaan atau indikator, hitung frekuensi jawaban setiap kategori (pilihan jawaban) dan jumlahkan. Setelah setiap indikator mempunyai jumlah, selanjutnya peneliti membuat garis kontinum.

$$
\text { Interval }=\frac{\text { Nilai Tertinggi }- \text { Nilai Terendah }}{\text { Jumlah Kelas atau Kelompok }}=\frac{4-1}{4}=0,75
$$

Berdasarkan rumus terebut nilai pernyataan pada hasil kuesioner dapat dilihat pada tabel berikut ini :

Tabel 1.

Penentuan nilai ukur pernyataan pada kuesioner

\begin{tabular}{|c|c|c|c|c|}
\hline Kelompok & $\begin{array}{c}\text { Batas } \\
\text { Bawah }\end{array}$ & Interval & Batas Atas & Keterangan \\
\hline 1 & 1,00 & 0,75 & 1,74 & Sangat tidak setuju \\
\hline 2 & 1,75 & 0,75 & 2,49 & Tidak setuju \\
\hline 3 & 2,50 & 0,75 & 3,24 & Setuju \\
\hline 4 & 3,25 & 0,75 & 4,00 & Sangat setuju \\
\hline
\end{tabular}

Berdasarkan tabel 1 diatas maka dapat dilihat nilai yang ditentukan sebagai berikut:

1. Nilai antara 1,00 sampai dengan $1,74=$ sangat tidak setuju

2. Nilai antara 1,75 sampai dengan $2,49=$ tidak setuju

3. Nilai antara 2,50 sampai dengan $3,24=$ setuju

4. Nilai antara 3,25 sampai dengan $4,00=$ sangat setuju

\section{Hasil Dan Pembahasan}

Tabel 2. Persepsi Responden terhadap Variabel Kinerja Pegawai (Y)

\begin{tabular}{|c|c|c|c|c|c|c|c|c|}
\hline \multirow[t]{2}{*}{ Item } & \multirow[t]{2}{*}{ Indikator } & \multirow{2}{*}{$\frac{\text { STS }}{1}$} & \multirow{2}{*}{$\frac{T S}{2}$} & \multirow{2}{*}{$\begin{array}{l} \\
3\end{array}$} & \multirow{2}{*}{$\begin{array}{c}\text { SS } \\
4\end{array}$} & \multirow[t]{2}{*}{$\mathbf{n}$} & \multicolumn{2}{|c|}{ Mean } \\
\hline & & & & & & & Item & Variabel \\
\hline Y1 & \multirow[t]{2}{*}{ Kualitas } & 0 & 0 & 16 & 20 & 36 & 3,56 & \multirow[t]{9}{*}{3,46} \\
\hline Y2 & & 0 & 4 & 16 & 16 & 36 & 3,33 & \\
\hline Y3 & \multirow[t]{2}{*}{ Kuantitas } & 0 & 2 & 18 & 16 & 36 & 3,39 & \\
\hline Y4 & & 0 & 3 & 12 & 21 & 36 & 3,50 & \\
\hline Y5 & \multirow{2}{*}{$\begin{array}{c}\text { Ketepatan } \\
\text { Waktu }\end{array}$} & 0 & 3 & 19 & 14 & 36 & 3,31 & \\
\hline Y6 & & 0 & 1 & 12 & 23 & 36 & 3,61 & \\
\hline Y7 & \multirow[t]{2}{*}{ Efektifitas } & 0 & 2 & 17 & 17 & 36 & 3,42 & \\
\hline Y8 & & 0 & 3 & 15 & 18 & 36 & 3,42 & \\
\hline Y10 & Kemandirian & 0 & 0 & 15 & 21 & 36 & 3,58 & \\
\hline
\end{tabular}


Berdasarkan tabel 2 di atas menunjukkan item yang memiliki skor rata-rata terendah adalah Y.5 yaitu selalu menyelesaikan pekerjaan sesuai dengan waktu yang ditentukan dengan nilai 3,31 dan item yang memiliki skor rata-rata tertinggi adalah Y.6 yaitu membuat target waktu untuk penyelesaian pekerjaan dan kegiatan dengan nilai 3,61

Skor rata-rata persepsi responden yaitu 3,46 dengan kategori sangat setuju, yang artinya responden sangat setuju bahwa kinerja yang baik akan membuat hasil pekerjaan menjadi maksimal dan memuaskan.

Berdasarkan hasil penelitian untuk nilai Tolerence variabel Gaya Kepemimpinan Demokratis, Motivasi dan Disiplin Kerja memiliki nilai Tolerence diatas $>0.10$ dimana untuk Gaya Kepemimpinan Demokratis dengan nilai 0,401, Motivasi dengan nilai 0,479 dan Disiplin Kerja dengan nilai 0,367. Semua variabel juga memiliki nilai VIF dari variabel diatas $<10.00$ yang menunjukkan bahwa model regresi tidak terjadi gejala multikolinieritas.

Analisis regresi linier berganda digunakan untuk mengetahui seberapa besar pengaruh variabel bebas yaitu: gaya kepemimpinan demokratis (X1), motivasi (X2), dan disiplin kerja (X3) terhadap variabel terikatnya yaitu kinerja pegawai (Y).

Dari hasil analisis tersebut dapat diketahui hasil analisis regresi linear berganda sebagai berikut.

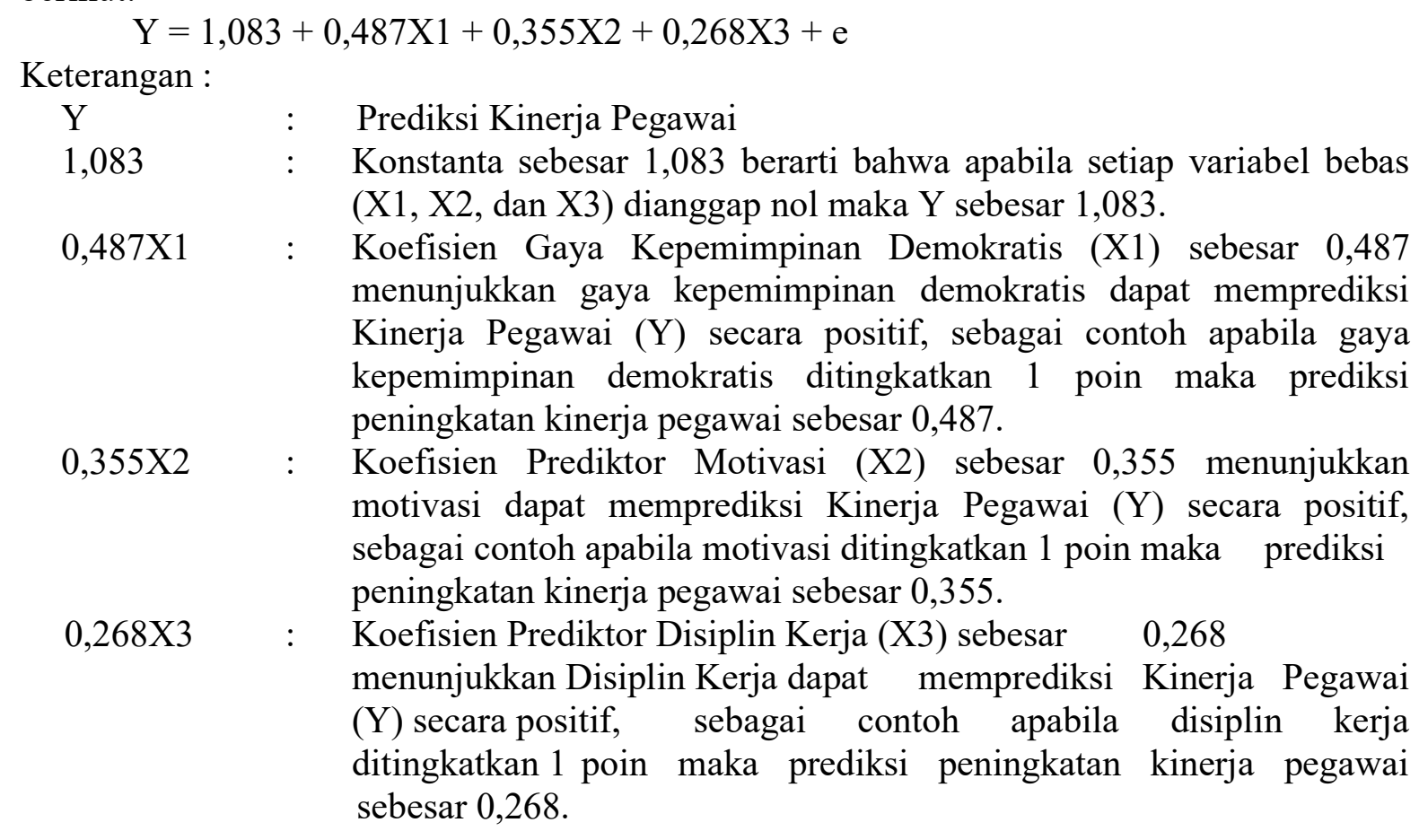

\section{Uji Validitas}

Uji validitas dilakukan dengan membandingkan nilai $r$ hitung dengan $r$ tabel untuk tingkat signifikansi 0,05 dari degree of freedom $(\mathrm{df})=\mathrm{n}-2$, dalam hal ini $\mathrm{n}$ adalah jumlah sampel. Jika $\mathrm{r}_{\text {hitung }}>\mathrm{r}_{\text {tabel }}$ maka pertanyaan atau indikator tersebut dinyatakan valid, demikian sebaliknya bila $r_{\text {hitung }}<r_{\text {tabel }}$ maka pertanyaan atau indikator tersebut dinyatakan tidak valid (Ghozali, 2013) 
Tabel 3. Hasil Uji Validitas

\begin{tabular}{|c|c|c|c|c|}
\hline Variabel & $\begin{array}{c}\text { Item } \\
\text { Pertanyaan }\end{array}$ & $\begin{array}{l}\text { Nilai } \\
\text { rhitung }\end{array}$ & $\begin{array}{c}\text { Nilai } \\
r_{\text {tabel }} \\
(n=36)\end{array}$ & Keterangan \\
\hline \multirow{7}{*}{$\begin{array}{c}\text { Gaya Kepemimpinan } \\
\text { Demokratis }\left(X_{I}\right)\end{array}$} & X1.1 & 0,788 & 0,329 & Valid \\
\hline & $\mathrm{X} 1.2$ & 0,548 & 0,329 & Valid \\
\hline & X1.3 & 0,611 & 0,329 & Valid \\
\hline & $\mathrm{X} 1.5$ & 0,803 & 0,329 & Valid \\
\hline & X1.6 & 0,803 & 0,329 & Valid \\
\hline & X1.7 & 0,532 & 0,329 & Valid \\
\hline & X1.8 & 0,788 & 0,329 & Valid \\
\hline \multirow{9}{*}{$\operatorname{Motivasi}\left(X_{2}\right)$} & $\mathrm{X} 2.1$ & 0,411 & 0,329 & Valid \\
\hline & $\mathrm{X} 2.2$ & 0,648 & 0,329 & Valid \\
\hline & $\mathrm{X} 2.4$ & 0,610 & 0,329 & Valid \\
\hline & $\mathrm{X} 2.5$ & 0,451 & 0,329 & Valid \\
\hline & $\mathrm{X} 2.6$ & 0,602 & 0,329 & Valid \\
\hline & $\mathrm{X} 2.7$ & 0,599 & 0,329 & Valid \\
\hline & $\mathrm{X} 2.8$ & 0,650 & 0,329 & Valid \\
\hline & $\mathrm{X} 2.9$ & 0,346 & 0,329 & Valid \\
\hline & $\mathrm{X} 2.10$ & 0,444 & 0,329 & Valid \\
\hline \multirow{8}{*}{ Disiplin Kerja $\left(X_{3}\right)$} & X3.1 & 0,520 & 0,329 & Valid \\
\hline & X3.2 & 0,525 & 0,329 & Valid \\
\hline & $\mathrm{X} 3.3$ & 0,395 & 0,329 & Valid \\
\hline & X3.4 & 0,778 & 0,329 & Valid \\
\hline & X3.6 & 0,587 & 0,329 & Valid \\
\hline & X3.7 & 0,516 & 0,329 & Valid \\
\hline & $\mathrm{X} 3.8$ & 0,352 & 0,329 & Valid \\
\hline & X3.9 & 0,585 & 0,329 & Valid \\
\hline \multirow{9}{*}{ Kinerja Pegawai (Y) } & Y1 & 0,481 & 0,329 & Valid \\
\hline & Y2 & 0,645 & 0,329 & Valid \\
\hline & Y3 & 0,711 & 0,329 & Valid \\
\hline & Y4 & 0,579 & 0,329 & Valid \\
\hline & Y5 & 0,490 & 0,329 & Valid \\
\hline & Y6 & 0,571 & 0,329 & Valid \\
\hline & Y7 & 0,548 & 0,329 & Valid \\
\hline & Y8 & 0,663 & 0,329 & Valid \\
\hline & Y10 & 0,367 & 0,329 & Valid \\
\hline
\end{tabular}

Sumber : Hasil Data Primer yang Diolah (2020)

Berdasarkan tabel 3 Hasil uji validitas terhadap item-item pernyataan pada tabel diatas membuktikan bahwa hasil korelasi dari setiap item menunjukkan bahwa $r_{\text {hitung }}>r_{\text {tabel }}$ pada tingkat signifikan 0,05 dengan $\mathrm{df}=\mathrm{n}-2=36-2=34$ sehingga hasilnya 0,329 . Dengan demikian dapat disimpulkan bahwa semua item pernyataan dinyatakan valid.

Pada penelitian ini, peneliti menghilangkan beberapa item pernyataan dikarenakan tidak memenuhi validnya hasil uji, diantaranya item X1.4 dengan nilai 0,174, X2.3 dengan nilai 0 . 292, X3.5 dengan nilai 0,251, X3.10 dengan nilai 0.319 dan Y9 dengan nilai 0.195.

\section{Uji Reliabilitas}

Pengukuran reliabilitas dilakukan dengan cara one shot atau pengukuran sekali saja dengan alat bantu SPSS uji statistik Cronbach alpha $(\alpha)$. Menurut Sujarweni V. (2015), kuesioner dikatakan reliabel jika nilai Cronbach alpha $>0,60$. 
Berikut adalah hasil pengujian reliabilitas dapat dilihat pada tabel 4 :

\begin{tabular}{|c|c|c|c|c|}
\hline & No & Variabel Penelitian & Crocbach alpha & Keterangan \\
\hline & 1 & $\begin{array}{l}\text { Gaya kepemimpinan } \\
\text { demokratis }\left(\mathrm{X}_{1}\right)\end{array}$ & $0,836>0,60$ & reliabel \\
\hline & 2 & Motivasi $\left(\mathrm{X}_{2}\right)$ & $0,695>0,60$ & reliabel \\
\hline & 3 & Disiplin Kerja $\left(\mathrm{X}_{3}\right)$ & $0,681>0,60$ & reliabel \\
\hline Tabel 4. Hasil Uji & 4 & Kinerja Pegawai (Y) & $0,749>0,60$ & reliabel \\
\hline
\end{tabular}

Berdasarkan tabel 4 diatas menunjukkan bahwa variabel memenuhi syarat reliabilitas karena nilai Crocbach alpha $>0,60$.

\section{Uji t}

Uji parsial digunakan untuk menguji signifikansi hubungan antara variabel $\mathrm{X}$ dan $\mathrm{Y}$, apakah variabel X1, X2, dan X3 (gaya kepemimpinan demokratis, motivasi dan disiplin kerja) benar-benar berpengaruh terhadap variabel Y (kinerja pegawai) secara terpisah atau parsial (Ghozali, 2013).

\begin{tabular}{|c|c|c|c|c|c|}
\hline \multirow[b]{2}{*}{ Model } & \multicolumn{2}{|c|}{$\begin{array}{l}\text { Unstandardized } \\
\text { Coefficients }\end{array}$} & \multirow{2}{*}{$\begin{array}{c}\begin{array}{c}\text { Standardized } \\
\text { Coefficients }\end{array} \\
\text { Beta }\end{array}$} & \multirow[b]{2}{*}{$\mathrm{t}$} & \multirow[b]{2}{*}{ Sig. } \\
\hline & $\mathrm{B}$ & Std. Error & & & \\
\hline 1 (Constant) & 1.083 & 1.913 & & .566 & .575 \\
\hline X1_GayaKep & .487 & .084 & .492 & 5.772 & .000 \\
\hline X2_Motivasi & .355 & .082 & .338 & 4.336 & .000 \\
\hline X3_Disiplin & .268 & .103 & .232 & 2.600 & .014 \\
\hline
\end{tabular}

a. Dependent Variable: Y_Kinerja

Berdasarkan tabel di atas melihat nilai signifikansi (sig.) dapat disimpulkan sebagai berikut :

1. Gaya Kepemimpinan Demokratis $\left(\mathrm{X}_{1}\right)$ memiliki $\mathrm{T}_{\text {hitung }} \geq \mathrm{T}_{\text {tabel}}$, dengan taraf signifikansi 5\% maka Ho ditolak dan Ha diterima, dimana 5,772 $\geq 2,036$.

2. Motivasi $\left(\mathrm{X}_{2}\right)$ memiliki $\mathrm{T}_{\text {hitung }} \geq \mathrm{T}_{\text {tabel }}$, dengan taraf signifikansi $5 \%$ maka Ho ditolak dan Ha diterima, dimana 4,336 $\geq 2,036$.

3. Disiplin Kerja $\left(\mathrm{X}_{3}\right)$ memiliki $\mathrm{T}_{\text {hitung }} \geq \mathrm{T}_{\text {tabel, }}$, dengan taraf signifikansi 5\% maka Ho ditolak dan Ha diterima, dimana 2,600 $\geq 2,036$.

\section{Uji F}

Dalam penelitian ini, Uji F digunakan untuk mengetahui tingkat siginifikansi pengaruh variabel-variabel independen secara bersama-sama (simultan) terhadap variabel dependen (Ghozali, 2013).

ANOVA $^{\mathrm{a}}$

\begin{tabular}{|l|ll|r|r|r|r|r|}
\cline { 2 - 7 } & Model & & Sum of Squares & df & Mean Square & F & Sig. \\
\cline { 2 - 8 } & Tabel 5. Hasil Uji & Regression & 306.083 & 3 & 102.028 & 103.738 & $.000^{\mathrm{b}}$ \\
& & Residual & 31.472 & 32 & .984 & & \\
& & Total & 337.556 & 35 & & & \\
\hline
\end{tabular}




\author{
a. Dependent Variable: $Y \_K i n e r j a$ \\ b. Predictors: (Constant), X3_Disiplin, X2_Motivasi, X1_GayaKep \\ Sumber : Hasil Data Primer yang Diolah (2020)
}

Berdasarkan tabel di atas meliat nilai signifikansi (sig.) yaitu sebesar 0,000 dan itu lebih kecil dari 0,05 maka dapat disimpulkan bahwa Gaya Kepemimpinan Demokratis $\left(\mathrm{X}_{1}\right)$, Motivasi $\left(\mathrm{X}_{2}\right)$, dan Disiplin Kerja $\left(\mathrm{X}_{3}\right)$ secara simultan berpengaruh signifikan terhadap Kinerja Pegawai (Y).

Dasar pengambilan keputusannya (Ghozali, 2013) adalah dengan menggunakan angka probabilitas signifikansi, signifikansi yang digunakan $(\alpha)$ sebesar 5\%. Sedangkan yang menjadi derajat kebebasan adalah $(\mathrm{df})=(\mathrm{n}-\mathrm{k}-1)$ dalam pengujian $\mathrm{F}_{\text {hitung }}$ dibandingkan $\mathrm{F}_{\text {tabel }}$. $F_{\text {hitung }}$ dalam penelitian ini adalah 2,90. Kriteria yang berlaku dalam uji $\mathrm{F}$ yaitu:

a) Apabila $F_{\text {hitung }} \geq F_{\text {tabel, }}$, dengan taraf signifikansi 5\% maka Ho ditolak dan Ha diterima., dimana $103,738 \geq 2,90$.

\title{
Analisis Koefisien Determinasi
}

Koefisien determinasi $\left(\mathrm{R}^{2}\right)$ pada intinya mengukur seberapa jauh kemampuan model dalam menerangkan variasi variabel terikat (Ghozali, 2016). Nilai Koefisien determinasi adalah antara nol dan satu.

Nilai $\mathrm{R}^{2}$ yang kecil berarti kemampuan variabel-variabel bebas (gaya kepemimpinan demokratis, motivasi dan disiplin kerja) dalam menjelaskan variasi variabel terikat (kinerja pegawai) amat terbatas.

\begin{tabular}{|l|c|r|r|r|}
\hline Model & \multicolumn{1}{|c|}{ Model Summary } \\
\hline 1 & $.952^{\mathrm{a}}$ & R Square & $\begin{array}{c}\text { Adjusted R } \\
\text { Square }\end{array}$ & $\begin{array}{c}\text { Std. Error of the } \\
\text { Estimate }\end{array}$ \\
\hline
\end{tabular}

Tabel 6. Tabel

Koefisien Determinasi

\author{
a. Predictors: (Constant), X3_Disiplin, X2_Motivasi, X1_GayaKep \\ b. Dependent Variable: Y_Kinerja \\ Sumber : Hasil Data Primer yang Diolah (2020)
}

Berdasarkan tabel 6. di atas dapat diketaui bahwa nilai koefisien determinasi terdapat nilai Adjusted R Square sebesar 0,898. Hal ini berarti kemampuan variabel bebas $\left(\mathrm{X}_{1}, \mathrm{X}_{2}\right.$, dan $\left.\mathrm{X}_{3}\right)$ dalam menjelaskan variabel terikat adalah sebesar $\mathrm{Kd}=0,898 \times 100 \%=89,8 \%$ sisanya $10,2 \%$ dipengaruhi faktor lain di luar model.

\section{Pengaruh Gaya Kepemimpinan Demokratis terhadap Kinerja Pegawai}

Gaya Kepemimpinan Demokratis secara parsial berpengaruh positif dan signifikan terhadap Kinerja Pegawai pada Kantor BAPELKES Provinsi Kalimantan Tengah. Hal ini dibuktikan dengan hasil statistik uji t untuk variabel gaya kepemimpinan demokratis dengan nilai thitung 5,772 lebih besar dari ttabel 2,036 dengan nilai signifikansinya 0,000 lebih kecil dari 0,05 dan koefisien regresi mempunyai nilai positif sebesar 0,487.

Kemudian jika dilihat dari hasil responden terhadap gaya kepemimpinan di BAPELKES pada pernyataan "pemimpin memberikan perhatian kepada seluruh pegawai untuk mencapai target yang diberikan" mendapat hasil yang tertinggi. Hal ini menunjukan pimpinan memiliki sikap perhatian terhadap pegawai atau bawahannya yang sangat baik, sehingga para pegawai 
merasa nyaman dan merasa diperhatikan dalam melakukan pekerjaannya karena dengan perhatian yang diberikan oleh pimpinan memberikan dampak yang sangat besar dalam mencapai target pekerjaan. Perhatian yang dilakukan seorang pimpinan merupakan suatu hal wajib karena sebagai figur seorang pemimpin harus senatiasa memberikan bimbingan dan panutan bagi perkembangan para pegawai atau bawahannya. Artinya semakin bagus perhatian yang diberikan kepada pegawai maka semakin meningkat juga secara keseluruhan kinerja untuk melakukan pekerjaan yang di Kantor BAPELKES. Berdasarkan hasil tersebut maka penelitian ini membuktikan hipotesis pertama yang menyatakan bahwa "Gaya Kepemimpinan Demokratis berpengaruh positif dan signifikan terhadap Kinerja Pegawai di Kantor BAPELKES Provinsi Kalimantan Tengah”.

Hasil ini didukung penelitian sebelumnya yang dilakukan oleh Tri Santi Octavia Olla, Struce Andriyani dan Leony Ndeon (2017) "Pengaruh Gaya Kepemimpinan Demokratis terhadap Kinerja Karyawan (Studi pada PT. Timor Express Intermedia Kupang)". Berdasarkan hasil penelitian tersebut hasil penelitian menunjukkan bahwa gaya kepemimpinan demokratis berpengaruh positif dan signifikan terhadap kinerja karyawan. Ini menunjukan bahwa kinerja yang dilakukan pegawai di Kantor BAPELKES sangat dipengaruhi oleh gaya kepemimpinan yang diterapkan karena pegawai memperhatikan pimpinan mereka sebagai panutan ataupun role model bagi mereka dalam melakukan setiap pekerjaan mereka.

\section{Pengaruh Motivasi terhadap Kinerja Pegawai}

Motivasi secara parsial berpengaruh positif dan signifikan terhadap Kinerja Pegawai pada Kantor BAPELKES Provinsi Kalimantan Tengah. Hal ini dibuktikan dengan hasil statistik uji $\mathrm{t}$ untuk variabel motivasi dengan nilai thitung 4,336 lebih besar dari ttabel 2,036 dengan nilai signifikansinya 0,000 lebih kecil dari 0,05 dan koefisien regresi mempunyai nilai positif sebesar 0,355 .

Kemudian jika dilihat dari hasil responden terhadap motivasi di BAPELKES pada pernyataan "hubungan yang terjalin antar pegawai sangat baik" mendapat hasil yang tertinggi. Hal ini menunjukan bahwa para pegawai yang berada di BAPELKES memiliki hubungan yang terjalin sangat baik, ini merupakan hal yang positif membuat suatu pekerjaan menjadi lebih ringan, rasa yang nyaman antara pegawai, serta kerja sama menjadi lebih mudah. Tentu saja sangat berdampak baik terhadap hasil pekerjaan dari para pegawai karena ketika suatu hubungan antar pegawai terjalin sangat baik akan membuat perasaan tenang, suasana menjadi tentram sehingga tidak adanya beban pikiran akibat perselisihan dan kecurigaan yang terjadi antar pegawai.

Dengan hubungan yang terjalin sangat baik meningkatkan motivasi yang dimiliki para pegawai dalam mengerjakan suatu pekerjaan. Dan juga hubungan sosial yang baik membuat rasa diterima di dalam kelompok. Berdasarkan hasil tersebut maka penelitian ini membuktikan hipotesis kedua yang menyatakan bahwa "Motivasi berpengaruh positif dan signifikan terhadap Kinerja Pegawai di Kantor BAPELKES Provinsi Kalimantan Tengah".

Hasil ini didukung penelitian sebelumnya yang dilakukan oleh Bryan Johannes Tampi (2014) "Pengaruh Gaya Kepemimpinan dan Motivasi Terhadap Kinerja Karyawan pada PT. Bank Negara Indonseisa, tbk (Regional Sales Manado)". Berdasarkan hasil penelitian tersebut hasil penelitian menunujukkan bahwa motivasi berpengaruh positif dan signifikan terhadap kinerja karyawan. 
Artinya motivasi yang dimiliki oleh pegawai di Kantor BAPELKES sudah baik sehingga kinerja yang dihasilkan juga sesuai dengan apa yang diharapkan.

\section{Pengaruh Disiplin Kerja terhadap Kinerja Pegawai}

Disiplin kerja secara parsial berpengaruh positif dan signifikan terhadap Kinerja Pegawai pada Kantor BAPELKES Provinsi Kalimantan Tengah. Hal ini dibuktikan dengan hasil statistik uji t untuk variabel Disiplin Kerja dengan nilai thitung 2,600 lebih besar dari ttabel 2,036 dengan nilai signifikansinya 0,014 lebih kecil dari 0,05 dan koefisien regresi mempunyai nilai positif sebesar 0,268 .

Kemudian jika dilihat dari hasil responden terhadap disiplin kerja di BAPELKES pada pernyataan "sikap saling menghormati antar pegawai di kantor" mendapat hasil yang tertinggi. Hal ini menunjukan bahwa para pegawai yang berada di BAPELKES memiliki sikap hormat yang sangat baik. Memiliki sikap kerja yang etis akan memberikan dampak yang baik bagi kinerja yang dilakukan oleh pegawai. Bekerja dengan taat dan memiki norma yang etis merupakan suatu yang sangat baik bagi pekerjaan yang dilakukan.

Pentingnya memiliki sikap saling mengormati memiliki manfaat seperti dapat meningkatkan hubungan baik antar pegawai, dapat mengurangi stress, menjadikan lingkungan kerja yang kondusif, meningkatkan produktivitas, memecahkan masalah dan mengurangi konflik, meningkatkan pengetahuan dan pemahaman (Van, 2018). Berdasarkan hasil tersebut maka penelitian ini membuktikan hipotesis ketiga yang menyatakan bahwa "Disiplin Kerja berpengaruh positif dan signifikan terhadap Kinerja Pegawai di Kantor BAPELKES Provinsi Kalimantan Tengah".

Hasil ini didukung penelitian sebelumnya yang dilakukan oleh Natalia Susanto (2019) "Pengaruh Motivasi Kerja, Kepuasan Kerja, dan Disiplin Kerja terhadap Kinerja Karyawan pada Divisi Penjualan PT. Rembaka". Berdasarkan hasil penelitian tersebut hasil penelitian menunujukkan bahwa disiplin kerja berpengaruh positif dan signifikan terhadap kinerja karyawan.

Ini menunjukan bahwa disiplin kerja yang dimiliki pegawai di Kantor BAPELKES sudah baik sehingga kepatuhan para pegawai akan membuat kinerja di BAPELKES juga akan meningkat.

\section{Pengaruh Gaya Kepemimpinan Demokratis, Motivasi, dan Disiplin Kerja terhadap Kinerja Pegawai}

Gaya Kepemimpinan Demokratis, Motivasi, dan Disiplin kerja secara simultan berpengaruh positif dan signifikan terhadap Kinerja Pegawai pada Kantor BAPELKES Provinsi Kalimantan Tengah.

Hasil ini terbukti dengan analisis menunjukan bahwa gaya kepemimpinan dmokratis, motivasi dan disiplin kerja secara bersama-sama memiliki pengaruh yang signifikan didukung oleh data yang diperoleh untuk R2 sebesar 0,898 untuk variabel Y (Kinerja Pegawai) atau $89,8 \%$ berarti terdapat pengaruh secara positif dan signifikan.

\section{Kesimpulan}

Dari analisis data yang dilakukan tentang penelitian yang berjudul "Pengaruh Gaya Kepemimpinan Demokratis, Motivasi dan Disiplin Kerja terhadap Kinerja Pegawai pada Kantor BAPELKES Provinsi Kalimantan Tengah”, dapat disimpulkan variabel Gaya 
kepemimpinan demokratis secara parsial berpengaruh positif dan signifikan terhadap kinerja pegawai, variabel Motivasi secara parsial berpengaruh positif dan signifikan terhadap kinerja pegawai, variabel Disiplin kerja secara parsial berpengaruh positif dan signifikan terhadap terhadap kinerja pegawai, variabel Gaya Kepemimpinan Demokratis, Motivasi dan Disiplin Kerja secara simultan berpengaruh positif dan signifikan terhadap Kinerja Pegawai dan Hasil uji koefisien determinasi melihat nilai R-square sebesar 0,898. Hal ini berarti kemampuan variabel bebas (X1, X2, dan X3) dalam menjelaskan variabel terikat adalah sebesar $\mathrm{Kd}=$ $0,898 \times 100 \%=89,8 \%$ sisanya $10,2 \%$ dijelaskan oleh variabel lain yang tidak dibahas dalam penelitian ini.

Peneliti mengharapkan kepada pimpinan maupun segenap pegawai di BAPELKES Kalimantan Tengah tetap memperhatikan berbagai aspek sumber daya seperti kedisiplinan, motivasi dan peran pimpinan yang dilakukan. Untuk pimpinan bisa lebih memperhatikan atau dapat menerima buah masukan saran dari para pegawai karena berdasarkan hasil data pengujian pada poin no 8 dengan pernyataan "pemimpin selalu memperhatikan buah pemikiran dari para pegawai" memliki mean terendah dengan 3,33. Selanjutnya lebih ditingkatkannya lagi terhadap kerja sama yang baik dilakukan oleh para pegawai dalam melakukan pekerjaan karna berdasarkan hasil mean pernyataan no 13 dengan penyataan "pegawai dapat bekerja sama dengan baik antara satu dan yang lain" memiliki mean terendah dengan 3,31.

Dalam hal kedisiplinan perlu juga perhatikan terhadap dalam hal kehadiran dari para pegawai karna berdasarkan hasil mean pernyataan no 20 dengan penyataan "selalu disiplin dalam hal presensi kerja (kehadiran) dari para pegawai" memliki mean terendah dengan 3,25 sehingga perlu dilakukan peningkatan kedisiplinan seperti memberikan sanksi yag sesuai. Sehingga diharapkan BAPELKES terus meningkatkan kualitas aspek-aspek tersebut jangan sampai terjadinya penurunan atau kurang diperhatikan supaya lebih meningkatkan kinerja dari pegawai.

Pada penelitian ini diketahui semua variabel bebas berpengaruh positif dan signifikan terhadap kinerja pegawai. Peneliti selanjutnya diharapkan mencari variabel-variabel lain yang kemungkinan berpengaruh juga terhadap kinerja pegawai selain variabel-variabel yang sudah diteliti pada penelitian ini misalnya beban kerja, pelatihan, lingkungan dan lainnya sehingga diharapkan penelitian lebih maksimal.

Peneliti selanjutnya diharapkan juga untuk meningkatkan jumlah sampel yang diteliti serta mencari objek lain untuk melakukan penelitian. Dapat menambah alat ukur dalam menilai variabel yang digunakan serta memperluas jumlah observasi dengan periode waktu yang lebih lama.

\section{Daftar Pustaka}

Anwar P. M.. (2005). Evaluasi Kinerja. Bandung : Refika Aditama

Bangun, Wilson. (2012). Manajemen Sumber Daya Manusia. Bandung : Erlangga.

Ghozali, I. (2013). Aplikasi Analisis Multivariate dengan Program SPSS. Semarang: BP Universitas Diponegoro. Semarang.

Handoko, T. Hani. (2008). Manajemen. Yogyakarta : BPFE. 
Hariyanto, A. E (2018). Pengaruh Gaya Kepemimpinan Demokratis, Motivasi, dan Disiplin Kerja terhadap Kinerja Karyawan pada Satuan Polisi Pamongpraja Kabupaten Tulungagung.

Hasibuan, M. (2012). Manajemen Sumber Daya Manusia. Jakarta : Bumi Aksara.

Ince, F. (2018). The Effect of Democratic Leadership on Organization Cynicism : A Study on Public Employees. Mersin, Turk.

Kasmir. (2016). Manajemen Sumber Daya Manusia (Teori dan Praktik). Depok. PT. Raja Grafindo Persada.

Ningih, Setia. (2017). Pengaruh Disiplin, Kompensasi dan Beban Kerja terhadap Prestasi Kerja Karyawan PT. Mega Finance Cabang Pekanbaru. Pekanbaru.

Nitisemito, A. S. (2010). Manejemen Personalia Manajemen Sumber Daya Manusia. Edisi Ketiga. Jakarta : Ghalia Indonesia.

Olla, T. S. O, Andriyani, S. dan Ndoen L. (2017). Pengaruh Gaya Kepemimpinan Demokratis terhadap Kinerja Karyawan (Studi pada PT. Timor Express Intermedia Kupang). Kupang.

Pirmanto, D., Jundillah, M. L., \& Widagdo, K. A. JENIS PENELITIAN MENURUT KEDALAMAN ANALISIS DATA.

Priyatno, Dwi. (2014). SPSS 22 Pengolahan Data Terpraktis. Yogyakarta : Andi

Pujihastuti, Isti (2010). Prinsip Penulisan Kuesioner Penelitian. Jurnal Agribisnis dan Pengembangan Wilayah, Vol. 2 No. 1 Desember 2010.

Quamila, A. 2021. Mengenal Lebih Dalam Gaya Kepemimpinan Demokratis dan Ciri Cirinya. Melalui https://glints.com/id/lowongan/gaya-kepemimpinandemokratis/\#.YIf9YLUza01 (09/Maret/2021)

Reza, R. A. (2010). Pengaruh Gaya Kepemimpinan, Motivasi Dan Disiplin Kerja Terhadap Kinerja Karyawan Pt Sinar Santosa Perkasa Banjarnegara. Banjarnegara.

Robbins, S. (2013). Manajemen, Edisi kedelapan / Jilid 2. Jakarta : PT. Grafindo.

Sekaran, U. dan Bougie R. (2017). Metodologi Penelitian untuk Bisnis Edisi 6. Salemba Empat. Jakarta.

Siagian, S. P. (2002). Kiat Meningkatkan Produktivitas Kerja. PT. Rineka Cipta. Jakarta.

Sugiyono. (2014). Metode Peneliian Pendidikan Pendekatan Kuantitatif, Kualitatif, dan $R \& D$. Bandung : Alfabeta.

Sujarweni, V.W. (2015). SPSS UNTUK PENELITIAN. Yogyakarta : Pustaka Baru Press.

Susanto, N. (2019). Pengaruh Motivasi Kerja, Kepuasan Kerja, dan Disiplin Kerja terhadap Kinerja Karyawan pada Divisi Penjualan PT. Rembaka. Agora, 7(1).

Tampi, B. J. (2014). Pengaruh Gaya Kepemimpinan dan Motivasi Terhadap Kinerja Karyawan Pada PT. Bank Negara Indonesia, tbk (Vols. III). Manado.

Terzi, A. R \& Derin R. (2016). Relation between Democratic Leadership and 
Organization Cynicism. Turkey.

Thoha, Miftah. (2010). Kepemimpinan Dalam Manajemen, Devisi Buku Perguruan Tinggi. Jakarta : PT. Raja Grafindo Persada.

Van, A.L. 2018. Manfaat dari pentingnya sikap menghormati dan menghargai dilingkungan kerja. Melalui https://www.umahliyu.com/2018/10/pentingnya-sikapsaling-menghormati- dan-menghargai-dilingkungan-kerja.html (05/11/2018)

Veithzal, Rivai dan Ella Jauvani Sagala. (2010). Manajemen Sumber Daya Manusia untuk Perusahaan. Cetakan ke 3. Jakarta : Rajawali Pers.

Wirawan. (2013). Kepemimpinan Teori, Psikologi, Perilaku Organisasi, Aplikasi \& Penelitian. Jakarta : Rajawali Pers.

Corresponding Author

e-mail:corresponding author 